\title{
REVIEW ON APPLICATION OF GASOLINE DIRECT INJECTION AND ADVANCED TECHNIQUES TO INCREASE EFFICIENCY AND MEET EURO-VI NORMS
}

\author{
Jai Shankar', Ashutosh Sahu² \\ ${ }^{1}$ Final year (B.Tech), Department of Mechanical Engineering, College of Engineering and Technology, \\ Bhubaneswar-751003, Orissa, India \\ ${ }^{2}$ Final year (B.Tech), Department of Mechanical Engineering, College of Engineering and Technology, \\ Bhubaneswar-751003, Orissa, India
}

\begin{abstract}
Nowadays, automobiles in the market are prone to heightened level of emissions due to fresh charge and scavenging losses. Furthermore, there is no practice of lean operation resulting in poor fuel economy. Carburetors have served the role of fuel supply system in spark ignition engines since a long time. Earlier due to the high initial cost and limited understanding, fuel injection system was used only in aircraft engines or racing cars. But due to increasing stress on air pollution control, the re is a strong need of adoption of technical amendments in the prevailing spark ignition engines. Hence this need gave rise to the development of newer systems like MPFI and GDI, which aim at satisfying the forthcoming stringent pollution norms. Also the innovations made needed to be affordable by the common people and also small in size so as to meet the space constraint. We made an attempt to compare the various fuel supply systems with special emphasis given on MPFI \& GDI. So the report aims to suggest a gasoline direct injection in automobiles to increase the efficiency as well as a reduction in emission levels so that it complies with the EURO-VI norms. The basic objectives of the report are:

(i) Incorporation of Gasoline Direct Injection in a 4-wheeler vehicle along with the inclusion of advanced technologies like EMS, turbo charging etc., for the overall engine improvement.

(ii) Basic downsizing principles and techniques like turbo charging to reduce cost, increase power output and improve efficiency.

(iii) Meet the existing EURO-VI emission norms, using EGR and controlling particulate matter emission.
\end{abstract}

Keywords: Euro-VI, EMS, piezoelectric injector, turbo charging, scavenging, downsizing

\section{INTRODUCTION}

Gasoline direct injection or GDI is an improvement to the widely used carburetor and port fuel injection systems. While the conventional multipoint system injects the air-fuel mixture into the intake manifold, GDI uses high-pressure gasoline directly into the combustion chamber

Although the air fuel mixture was previously prepared outside the cylinder before its injection, GDI sprays only fuel and mixing takes place later inside the chamber [1]. Thus the fuel gets very less time to get atomized and mix thoroughly with air. Hence to make this possible the fuel mixture has to be injected in the form of very fine droplets (up to diameter 20 microns) which is only possible at extremely high pressures. Thus an additional high-pressure fuel pump is required which draws its power from the engine crankshaft. During the induction stroke, only air is supplied into the chamber. This helps in attaining higher compression ratios without worrying about knocking as well as increases volumetric efficiency of the intake stroke. [6]
Some of the advantages of GDI are:

(i) It avoids sticking of the fuel to the walls of the intake manifold.

(ii) Due to the absence of the throttle plate throttling losses are reduced greatly

(iii) Improved accuracy in achieving the required air fuel ratios at various loads.

(iv) Higher Compression ratios can be established which increases thermal efficiency, volumetric efficiency, and fuel economy.

(v) Heat losses, engine emissions (NOX and CO2) are reduced.

(vi) Better cold starting performance and increased driver comfort.

Yet after so many noteworthy and helpful advantages, GDI has got its own disadvantages which make it difficult to be used in the most commonly used vehicles. They are:- 

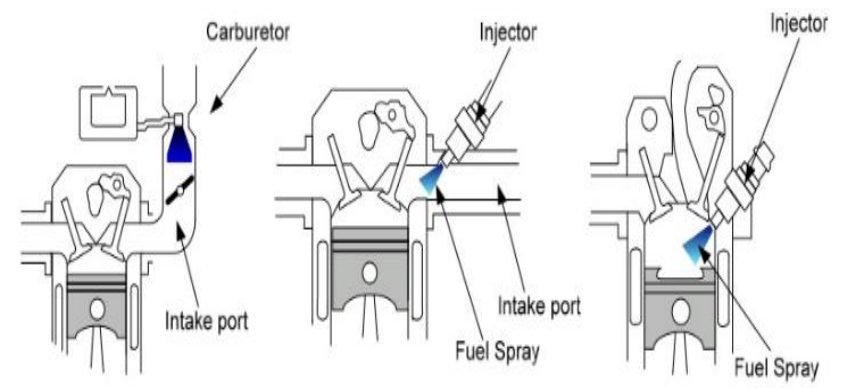

\section{Carburetor}

Port Fuel Injection

Fig 1:- Mixture formation systems in gasoline engines [8]

(i) Increase in a number of particulate matter emissions (PME) during engine operation.

(ii) The engine becomes heavier and bulkier due to the usage of additional components making it necessary to implement engine downsizing. This is expected to reduce the vehicle cost that may have increased due to the incorporation of highly advanced mechanisms.

Table 1:- Comparis on between GDI and PFI engines [8]

\begin{tabular}{|c|c|c|c|c|c|c|c|}
\hline $\begin{array}{l}\text { Engine } \\
\text { Type }\end{array}$ & $\begin{array}{l}\text { Swept } \\
\text { volume }\end{array}$ & Max. Power & $\begin{array}{l}\text { Max. } \\
\text { Torgue }\end{array}$ & $\begin{array}{l}\text { Mixture } \\
\text { formation } \\
\text { system }\end{array}$ & $\begin{array}{c}\text { Fuel economy } \\
\text { (urband driving }) \\
\text { L/100km }\end{array}$ & $\begin{array}{c}\text { Fuel economy } \\
\text { (hightway } \\
\text { driving) } \\
\text { L/100km }\end{array}$ & $\begin{array}{l}\mathrm{CO}_{2} \\
\text { emission } \\
\mathrm{g} / \mathrm{km}\end{array}$ \\
\hline $\begin{array}{l}\text { Gasoline } \\
\text { enguine }\end{array}$ & $1.6 \mathrm{~L}$ & $\begin{array}{c}75 \mathrm{~kW} \\
56001 / \mathrm{min}\end{array}$ & $\begin{array}{c}148 \mathrm{Nm} \\
38001 / \mathrm{min} \\
\end{array}$ & $\begin{array}{c}\text { PFI (port tuel } \\
\text { iniection) }\end{array}$ & 10,5 & 6,0 & 179 \\
\hline $\begin{array}{l}\text { TSI } \\
\text { gasoline } \\
\text { engine }\end{array}$ & $1.4 \mathrm{~L}$ & $\begin{array}{c}90 \mathrm{~kW} \\
5000 \cdot 5500 \\
1 / \mathrm{min}\end{array}$ & $\begin{array}{c}200 \mathrm{Nm} \\
1500 \cdot 4000 \\
1 / \mathrm{min}\end{array}$ & $\begin{array}{l}\text { GDI (Gasoline } \\
\text { directimection) }\end{array}$ & 8,6 & $5 j$ & 157 \\
\hline
\end{tabular}

(iii) Design of sophisticated fuel injectors that spray the fuel at very high pressures as well as respond quickly to the required engine conditions [4].

(iv) GDI demands frequent cleaning of the injector valves as increased dust depositions can clog them thereby reducing the fuel injection pressure.

(v) It uses a highly accurate Engine Management System (EMS) along with advanced sensors to feed data about the engine conditions to the control unit to monitor the injection amount and timing. Highly trained professionals can only be employed for servicing for such complex mechanisms.

So we aim to come up with solutions that either reduce or eliminate the above-mentioned disadvantages. Our other goals are to ensure that the emissions values comply with the Euro-VI norms.

\section{GASOLINE DIRECT INJECTION IN FOUR}

\section{WHEELERS}

The primary advantage of GDI over PFI is the difference in the air fuel mixture ratio at various loads and the way of an injection of fuel into the combustion chamber. In PFI engines, there is limited scope for improvement of the economy as the compression ratio cannot be increased. This is because the PFI works at a chemically correct ratio at all loads, increasing which, results in the higher chances of knocking. However, in GDI, the lean mixture is supplied and it operates under un-throttled conditions at part loads (where the supply of fuel-rich mixture is not necessary). Here fuel is injected just before sparking and air fuel ratio greatly varies throughout the cylinder. Only the region around the spark plug experiences a fuel rich mixture while leaner mixtures are available at all other places. This implies improved fuel economy.

At full load conditions, chemically correct/ slightly rich homogeneous mixture is supplied which results in better output and thus better efficiency. Here fuel is fed during the intake stroke. Due to this timing, the injected fuel evaporates and draws much heat from the intake charge. This cooling effect produced hence checks knocking.

In GDI engines, the charging of fuel is done by two ways one is the stratified method and the other one is homogeneous method. The stratified charge mode is used at partial load conditions and fuel injection takes place during the compression stroke. The engine is capable of being operated at an air-fuel ratio greater than 100 along with fully un-throttled operation. However, the engine maybe slightly throttled and the air fuel ratio kept in between 30 to 40 . This helps in facilitating of high amount exhaust gas during EGR and creation of vacuum during application of air brakes. Here the engine load can be adjusted by changing the air fuel ratio.

A homogeneous charge is supplied at higher load conditions where the fuel is injected during the intake stroke. During most of the process, engine operation is done at chemically correct or slightly rich mixture at full load. For minimizing the fuel consumption, the engine can also be operated at the air-fuel ratio between 20 and 25 . Here air-fuel ratio remains same throughout whereas engine load is varied. [8]

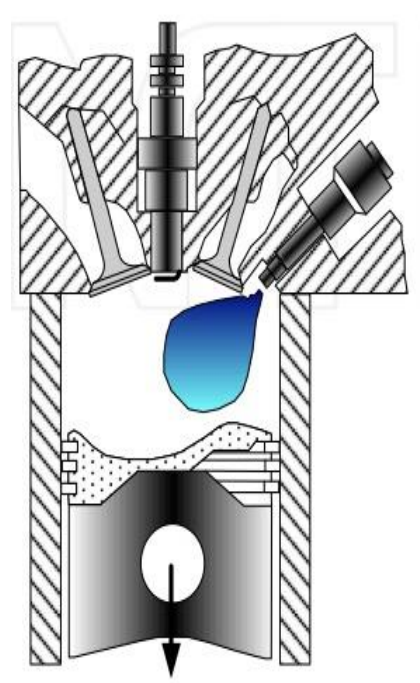

Homogeneous charge

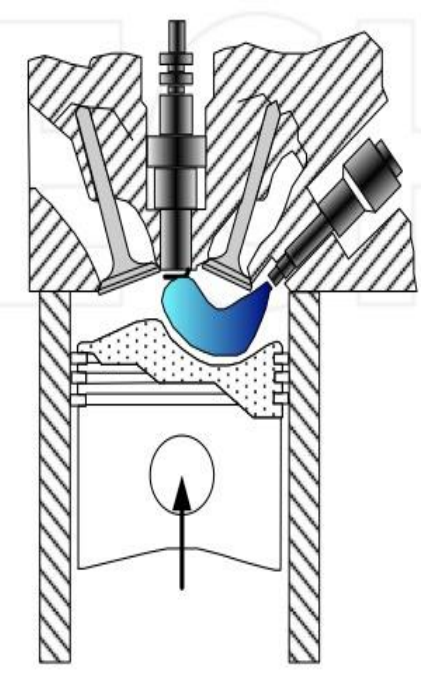

Stratified charge
Fig 2:- Types of charging modes [8] 
During stratified charge operation, 3 types of combustion systems can be used for the formation of ignition mixture near the spark plug. They are air-guided, wall guided and spray guided system. They can be distinguished by the process in which the fuel spray reaches the spark plug.

In the wall guided system, here a specially shaped piston surface is needed. During injection, the fuel does not evaporate fully and thus $\mathrm{HC}$ and $\mathrm{CO}$ emissions increase. This results in a drop of fuel economy and therefore a wall guided system alone is not desirable.

In the case of air guided systems, here the fuel is supplied along with the airflow which helps in moving the fuel cloud towards the spark plug. The air flow is obtained by the use of specially shaped inlet ports while the air speed is varied with the help of air baffles in the intake manifold. [3]

Most of the GDI engines prefer using the wall guided system along with usage of an intense flow of air (swirl or tumble flow). When both these systems are used in collaboration, the fuel injectors are placed remotely to the spark plug.

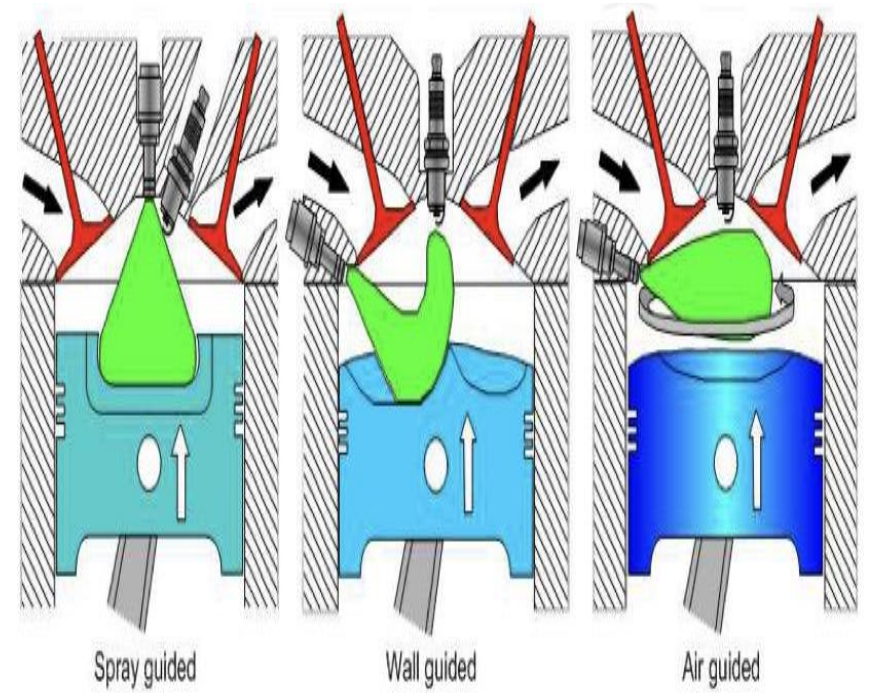

Fig 3:- Types of guided combustion systems at stratified charge. [8]

The spray guided combustion system, theoretically, is the most efficient one. Here the fuel is injected in the form of a spray, right next to the spark plug, where it evaporates immediately. This process needs to be incorporated with advanced injector systems like piezoelectric injection systems. They work on the principle of piezoelectricity which is used in opening and closing of the fuel injectors at high accuracy. They consist of a numerous number of piezoelectric crystals which can expand when electricity is passed through them. Thus upon passage of electricity, the injectors are opened and closed immediately upon stopping the current flow. Although making piezoelectric injectors work isn't easy, they have certain benefits over conventional solenoid injectors that justify all of the other. Some of the benefits are: (i) GDI Engines demands a precise control of the injection intervals which decides the amount of fuel sprayed in the engine. This requirement is met by piezoelectric injectors as they open and closes much faster than conventional injectors.

(ii) Capable of providing feedback by producing fluctuations in the electricity used for their activation. This, in turn, helps in accurate fuel metering which increases fuel economy and reduces emissions.

(iii) The expansion of the piezoelectric crystals can be controlled by varying the amount of electric current. So when a little less electricity is applied, the piezoelectric crystals expand less which helps the injectors to open partway. Smaller opening results in a longer injection time. This helps in maintaining the accuracy of tiny fuel injections whenever needed.

(iv) Due to their swift operation, they are capable of injecting multiple times during a single combustion cycle. This helps in further reduction of emissions as well as limiting of soot.

Some of the disadvantages include fouling of the spark plug and high sensitivity when ignition and injection timings are varied. The advantages include reduced wall-wetting and $\mathrm{HC}$ emissions, less sensitivity during cylinder-to-cylinder variations and in-cylinder airflow. During this mode, the engine runs with the greater bulks of air which results in better fuel economy. [7]

\section{ENGINE MANAGEMENT SYSTEM AND}

\section{FUEL INJECTION SYSTEM}

\subsection{The Fuel Injection System}

The GDI engine demands highly atomized and stratified fuel to be available to the compressed air during the power stroke at the spark plug. Hence this type of engine has its own set of fuel condition requirement without which it can't work at its maximum efficiency.

Hence for the achievement of highly discrete fuel particles, the first and foremost condition is to spray the fuel at very high pressures. In case of the conventional PFI system, the common pressure range at which the fuel is injected, varies from $0.25 \mathrm{MPa}$ to $0.45 \mathrm{MPa}$ only. On the other hand, GDI needs a very high pressure level ranging from $4 \mathrm{MPa}$ to 13 $\mathrm{MPa}$. Such high pressures result in better atomization (reducing the fuel droplet size up to $20 \mu \mathrm{m}$ ) as well as increases the penetration distance into the cylinder during the compression stroke. However this meritorious penetration distance may also lead to serious problems such as wall wetting. Hence there is always a limit on the high pressure that should be employed for injection. Also some modifications in the positioning of the injector are required to match with the requirements and also avoid wall wetting.

The basic and necessary components of a fuel supply system for a GDI engine are as follows.

(i) Fuel Tank

(ii) Low Pressure Pump 
(i) Fuel Filter

(ii) High Pressure Pump

(v) Fuel Rail

(iii) High Pressure Sensor

(iv) Fuel Injector

(v) Fuel pressure control valve

The whole systemcomprises of two sections:-one is the high pressure line and the other is the low pressure line. The fuel pressure inside the low pressure line is generally maintained from 0 to 5 bars. After the fuel passes through the high pressure line, just before the fuel injection, the pressure delivered is about 4-13 $\mathrm{MPa}$. [8]

The fuel storage tank stores the fuel. It is delivered from the tank to the high pressure line into the high pressure pump by the help of an electrically driven fuel pump i.e., the low pressure pump at $0.35 \mathrm{MPa}$. The low pressure pump is located near or inside the fuel tank itself and does the work of transporting fuel from the low pressure line to the high pressure line.

Once the required amount of fuel that is to be injected at one time, enters the high pressure line, it is first made to pass through a fuel filter. Like any basic filter, this fuel filter too eliminates the dust or other impurities present in the fuel bulk. Without filtering, the impure fuel may contain contaminants which upon combustion can form gum and slag that can stick to cylinder walls, valve seats and piston rings, thereby reducing volumetric efficiency and increasing emissions.

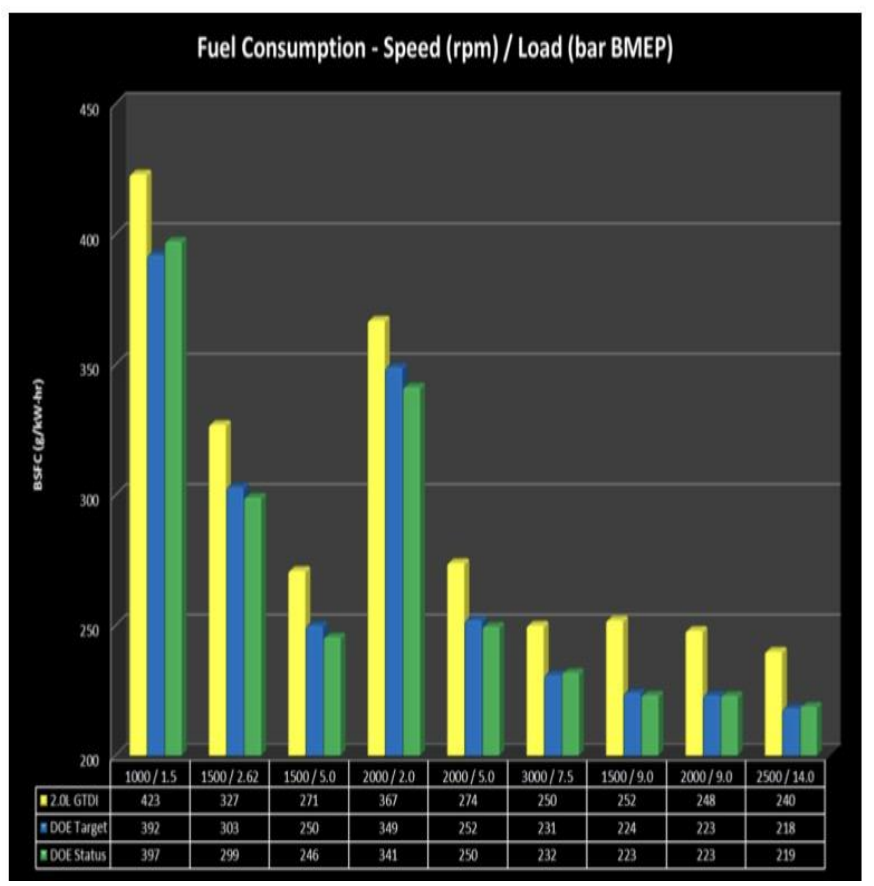

Fig 4:-Fuel consumption vs. speed graph. [10]

After the clean fuel enters the high pressure line successfully, it is then sent into the high pressure pump. It draws power from the camshaft of the engine itself and increases the fuel pressure up to $13 \mathrm{MPa}$. This pressurised fuel is then sent to the fuel rail. The pressure, to which the fuel is elevated by the high pressure pump, is determined by application data drawn from the various sensors for the operating conditions of the engine. The fuel rail consists of the high pressure sensor to determine the fuel pressure inside the rail, the pressure maintained between $4 \mathrm{MPa}$ to 13 MPa.

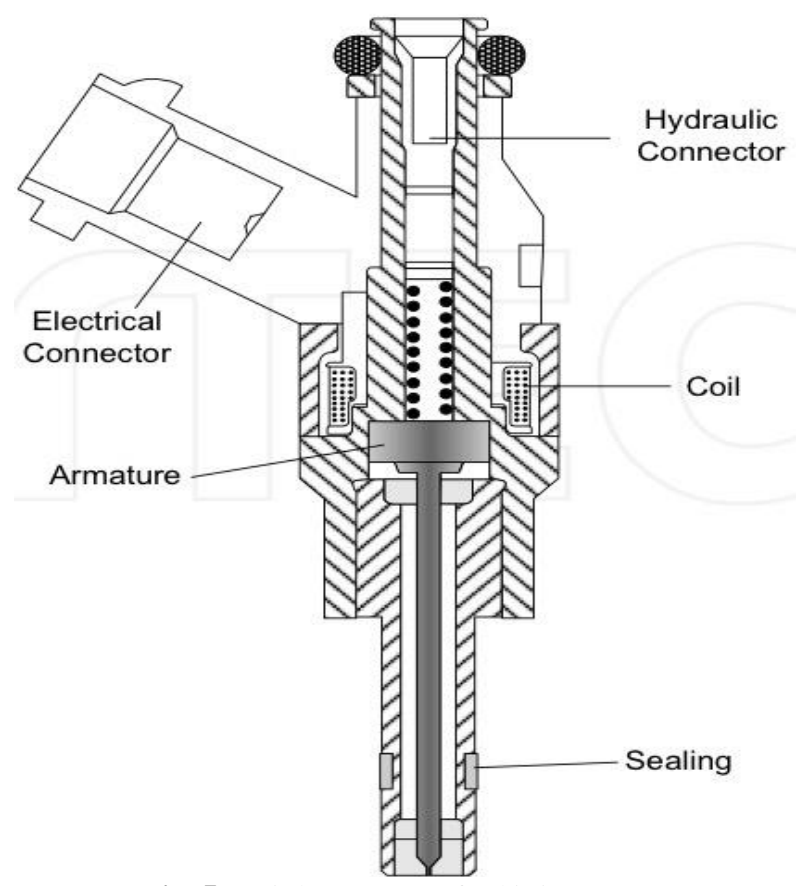

Fig 5:- High pressure fuel injector. [8]

Maintaining a constant pressure throughout the rail up to the injector tip is very important keeping in mind the adverse effects of variable and non-uniform pressure on engine power, efficiency, noise and emissions etc. These variations from the desired value are adjusted by using an open-loop or closed-loop control valve. The function of this valve is to send back the extra fuel into the fuel tank.

It is the fuel rail that provides for the accumulation of the fuel. Various components like the injectors, high pressure sensor and the pressure control valve are planted on the rail (acting as a base). Among all of the above stated components, the injector is the most vital and sensitive component in the whole fuel supply system for a GDI engine. It is located between the combustion chamber and the rail. It contains very minute openings to spray very fine droplets of fuel and a highly sensitive actuator that responds to the commands of engine control unit instantly.

\subsection{The Engine Management System (EMS)}

The engine management system (EMS) comprises the following units and components:-

1. Electronic Engine Control Unit

2. Various sensors, each employed to record a particular data and send the information to the ECU.

3. Actuators, meant to take actions according to commands of the ECU. 
The ECU continuously selects the one out of the available operating modes depending on engine operating point and sensor's data. The ECU instructs the actuators based upon input signals captured by sensors. The ECU controls their action to act at the right time and place. This regulates fuel injection functions and ignition timing, EGR system, idle time, fuel-vapour retention system, electric fuel pump and operating of the other systems. The engine management systems must have very robust and flawless algorithms fed into its control system to ensure up-to-the-mark performance and driveability. Hence the ECU must be designed for sufficient memory, clock speed, and sophisticated processing units.

Inputs (sensors): The various sensors are used to provide the engine control unit data about the prevailing engine operating conditions. This data feed helps the ECU in deciding necessary actions to be followed under those conditions and to send requisite orders to the actuators. Mass air flow sensor, intake air temperature sensor, engine temperature sensor, intake manifold pressure sensor, engine speed sensor, camshaft position sensor, throttle position sensor, accelerator pedal position sensor, rail fuel pressure sensor, knock sensor, lambda sensor upstream of primary catalytic converter, lambda sensor downstream of primary catalytic converter, exhaust gas temperature sensor, lambda sensor downstream of main catalytic converter are some of the sensors used in a typical GDI engine management system.

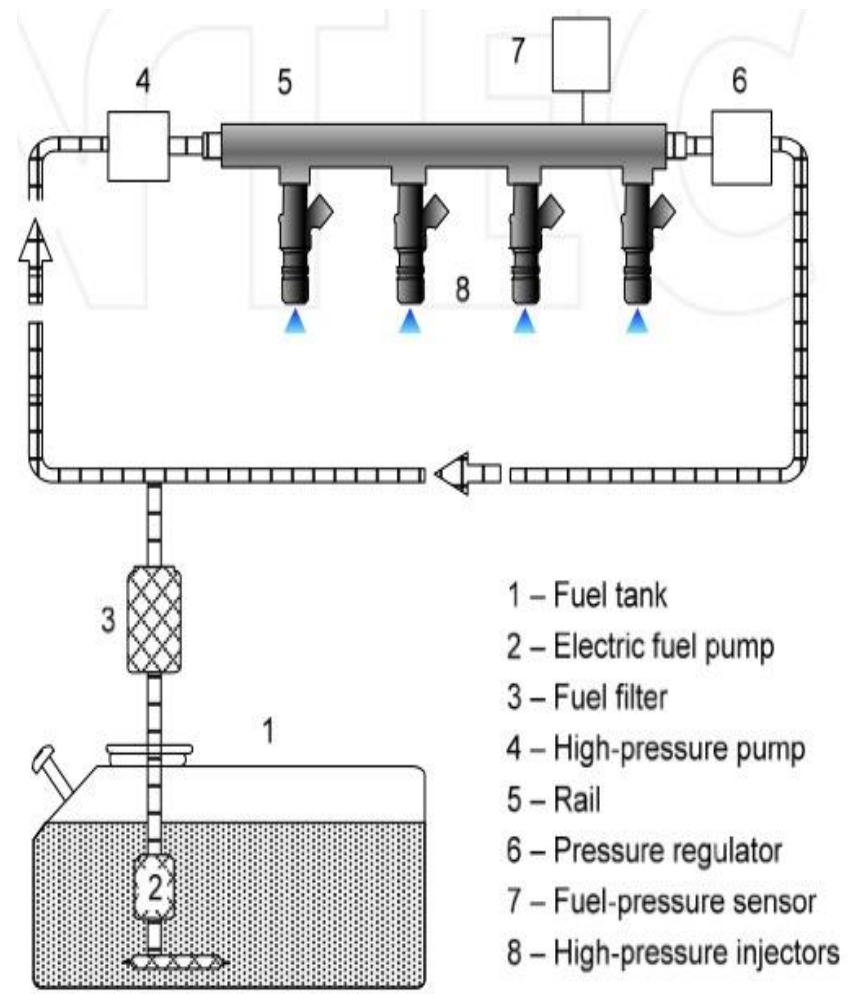

Fig 6:- Components of ECU. [8]

Outputs (actuators): The control unit obtains valuable data about the current condition at various points inside the engine manifold and then take necessary adjustment measures by the help of actuators such as Fuel injectors, ignition coils, throttle valve positioned, electric fuel pump, fuel pressure control valve, EGR valve, fuel-vapour retention system valve and fan control.

\section{TURBOCHARGING AND SCAVENGING}

\subsection{Turbo Charging}

The GDI engine can also be turbocharged which basically means to increase the engine efficiency and power output by the usage of a forced induction device. This induction device helps in improving the engine aspiration and is powered by a turbine. In contrast to a supercharged engine where the turbine is driven by the engine crankshaft, the turbine here is powered by the engine's exhaust gases.

The turbine in turn rotates an air compressor interconnected by a shaft. The compressor sucks in atmospheric air and compresses it thereby increasing its density. Now the compressed air is again passed through a charged air cooler which further increases the air density by reducing its temperature to a great extent.

Hence this increase in air density helps in filling up the limited cylinder volume with heavy amount of air that won't have been achievable using natural aspiration of the engine. This results in an improvement in the volumetric efficiency of the engine.

In simpler words, more air implies better combustion which means more power per engine cycle.

Though the supercharged engines come with the added advantages of better response to a throttle change, we chose the turbocharged engine as we were concerned in improving the engine efficiency. The super charged engines being fed power from the engine crankshaft have substantially less fuel efficiency.

\subsection{Scavenging}

Gasoline direct injection engines use turbochargers to increase the fuel intake economy. In addition to this, another technique, well known as "scavenging" is also used to get extra benefits and overcome some issues that arise due to turbo charging. Scavenging leverages the synergies obtained from gasoline direct injection, and turbo charging.

The functioning of scavenging technique takes place as follows. It controls the valve operation so that during lower speeds of engine, both the valves are simultaneously open for a small time. These results in an intense dynamic pressure difference between the inlet and exhaust valves. Large amounts of fresh air are drawn into the combustion chamber and this eliminates the residual useless gases more effectively out of the cylinder. The electronic engine management system (EMS) carries out this operation at proper timing by the proper instructions to the valve actuators, thus adjusting the charge to an optimum level and controlling the combustion process. [2] 
At low engine speeds, the intake valve is closed early and the injection takes place a bit later. This results in a substantial increment in the amount of air being charged since less amount of air is able to go into the intake port. This effect is carried out by proper adjustment of the camshaft driving the valves.

The higher mass throughput thus adds to efficiency of the turbocharger. This happens because its operating point is elevated to a much higher charge speed with higher charge pressure. When the engine RPM is below 2000, the increase rate of torque at full load can be improved so much that the response of the engine becomes equivalent to that of large displacement engines. When compared with the PFI engines having the same power output, the fuel consumption in this case is observed to be reduced by around $15 \%$.

\section{EXHAUST EMISSIONS IN GDI}

\subsection{Emission Types}

The carbon monoxide emissions in GDI are primarily dependent upon $\mathrm{A} / \mathrm{F}$ ratio. They increase with an increase in the $\mathrm{A} / \mathrm{F}$ ratio. As the air fuel mixture varies during GDI engine operation I.e. Leaner mixture in case of part loads and the stratified mixture at full loads, this implies that $\mathrm{Co} 2$ emissions are already pretty low and fall with the emission norms.

As hydrocarbon emissions are somewhat a function of temperature, their amount may be slightly increased during cold starting. Also they may be increased due to the liquid fuel entered into the combustion chamber. Still the amounts released are well within the emission norms and are not a concern.

NOX emissions must be significantly reduced during GDI engine operation as they are appreciable when high cylinder temperatures are attained. NOX emissions are also high at higher torque output and during full load conditions as they result an increase in temperature.

\subsection{Euro-VI Norms}

For complying with the Euro 6 emission controls the values must be lesser than the corresponding values mentioned below:

Table 2: Euro VI emissions norms [9]

\begin{tabular}{|c|c|c|c|c|c|c|c|c|}
\hline Tier & Date & co & THC & NMHC & $\mathrm{NO}_{\mathrm{x}}$ & $\mathrm{HC}+\mathrm{NO}_{\mathrm{x}}$ & PM & pa.. \\
\hline \multicolumn{9}{|l|}{ Diesel } \\
\hline Euro $1+$ & July 1992 & $2.72(3.16)$ & . & - & - & $0.97(1.13)$ & $0.14(0.18)$ & - \\
\hline Euro 2 & January 1996 & 1.0 & - & - & - & 0.7 & 0.08 & - \\
\hline Euro 3 & January 2000 & 0.64 & - & - & 0.50 & 0.56 & 0.05 & - \\
\hline Euro 4 & January 2005 & 0.50 & - & - & 0.25 & 0.30 & 0.025 & - \\
\hline Euro 5 & September 2009 & 0.50 & - & - & 0.180 & 0.230 & 0.005 & - \\
\hline Euro 6 (future) & September 2014 & 0.50 & - & - & 0.080 & 0.170 & 0.005 & - \\
\hline \multicolumn{9}{|c|}{ Petrol (Gasoline) } \\
\hline Euro $1 \dagger$ & July 1992 & $2.72(3.16)$ & - & - & - & $0.97(1.13)$ & - & - \\
\hline Euro 2 & January 1996 & 2.2 & - & - & - & 0.5 & - & - \\
\hline Euro 3 & January 2000 & 2.3 & 0.20 & - & 0.15 & - & - & - \\
\hline Euro 4 & January 2005 & 1.0 & 0.10 & - & 0.08 & - & - & - \\
\hline Euro 5 & September 2009 & 10 & 0.10 & 0.068 & 0.060 & - & $0.005^{* *}$ & - \\
\hline Euro 6 (future) & September 2014 & 1.0 & 0.10 & 0.068 & 0.060 & - & $0.005^{* *}$ & - \\
\hline
\end{tabular}

The control of NOX and particulate matter emissions are not a major concern while designing our engine as they are much similar to the previous emission control norms .However stricter numbers are assigned for NOX emissions as well as particulate matter.

Coincidentally the GDI engine will have high NOX and particulate matter emissions due to the significant improvement in its combustion efficiency. So our main focus will be on limiting the amount of NOX as well as PME. NOX emissions were controlled by implementing EGR which PME was controlled by usage of specially designed catalytic converters.

\section{EXHAUST EMISSION CONTROL}

\subsection{Exhaust Gas Recirculation}

Exhaust gas recirculation is the technique in which the amount of NOX emissions is reduced in order to comply with the existing standard emission norms like Euro-VI.

Now the idea here is to limit the amount of fresh air into the combustion chamber. This is because an abundance of oxygen means better combustion efficiency. But it also results in an appreciable increase in cylinder temperature and pressure. At temperatures exceeding $2400 \mathrm{~K}$ the NOX emissions are relatively higher.

So in EGR, some portion of exhaust gas is taken up first. The gas is then cooled to increase its density and is fed into the combustion chamber. Here the exhaust gases are mixed with fresh air. They help in diluting the amount of oxygen inside the incoming air stream during suction stroke. The exhaust gases are also referred to as charged or inert air as they are incapable of undergoing combustion. Due to the supply of exhaust gases the amount of fresh air or oxygen drops as they displace some amount of combustible matter. Due to drop in oxygen amount, the combustion is reduced slightly and the inert gases also help in absorbing some of the heat energy produced. Hence peak combustion temperature is reduced which means we are successful in reducing the amount of NOX emissions.

\subsection{Particulate Matter Emission and its Control}

When it comes down to the issue of intensively harmful emissions by an engine, two cases are possible as follows.

(i) Gaseous emissions- the harmful gases formed during the combustion process such as oxides of carbon, nitrogen, sulphur as well as unburnt hydrocarbons

(ii) Particulate matter- such as soot, ash etc.

(iii) Keeping in mind the environmental norms and various emission control standards, the emission levels from this combustion have to be kept in check. Thus the exhaust gases needed to be treated before they can be allowed to diffuse to the atmosphere outside the exhaust pipe.

The main topic of concern as per particulate matter emissions are considered is about the soot and ash formed in 
the GDI engine. This soot can oxidize at five times faster rate than that produced in diesel engines. Also when the engine is running at very high speeds, ash is formed. Both the matter is harmful for the engine system as well as the environment also.

An effective method to reduce the particulate matter emissions is to make the exhaust gas pass through specially designed "ceramic honeycombs". These structures contain multiple cells resembling to the combs made by the honeybees to save honey. Here also, the cells are made up of porous walls that help to entrap the particulate emissions when the exhaust gas passes through them. The dimensions of the porous walls are cited as - a thickness of about $150 \mu \mathrm{m}$ to $750 \mu \mathrm{m}$ and the effective wall permeability of about $0.8 \times 10^{-12} \mathrm{~m}^{2}$. There may be as many as 40,000 to 250,000 cells inside the honeycomb.

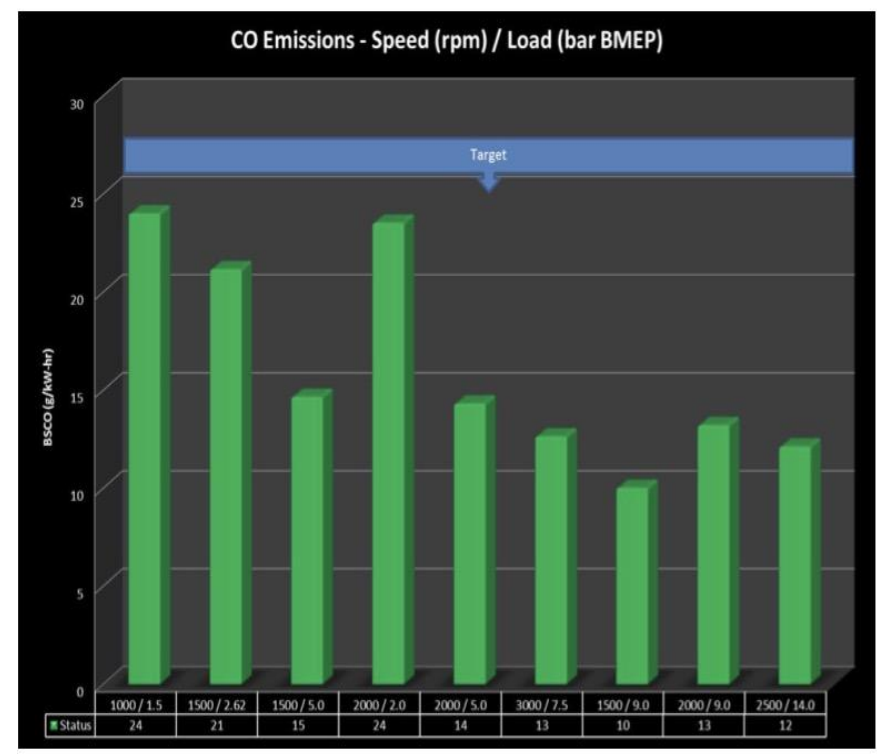

Fig 8:-CO emissions vs. speed graph [10]

The "honeycombs" are basically filters. These have cells aligned axially extending throughout the length of the filter from the inlet up to the outlet. Porous walls are present as a divider between the cells. The arrangement of the cells inside the structure is well planned such that the exhaust gas has to anyway pass through these cells before escaping out of the filter thereby ensuring its filtration. In this process the particulate matter is left back at the pores and settles down at the cell base.

The formation of soot inside the GDI engine is very dangerous and vulnerable for the engine systems as it generates at times very thick soot and causes a back pressure. Hence it is necessary for the filter to work efficiently even at lower pressure drops. [5]

\section{ENGINE DOWNSIZING}

Engine downsizing, in a layman's words means reducing the overall size of the engine. It can be achieved by two ways:-

(i) By reducing the dimensions of the engine while keeping the power output levels constant (ii) Or, by increasing the power output levels at the same engine size, the increment which would have been possible only by a bigger engine.

Hence, depending on the requirement and constraints like space, cost, technology etc., one of the above stated processes is employed.

In case of two wheelers, where the space is limited, engine downsizing plays a very important role in achieving economic results. Also for the successful working of Gasoline Direct Injection, smaller size of engine is very useful.

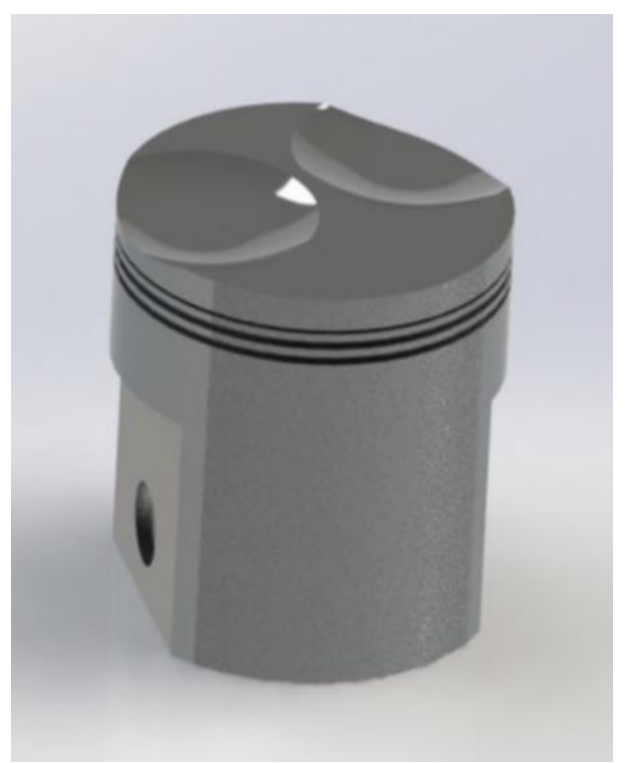

Fig 9:- Is ometric view of piston

Smaller engines would give out lesser emissions in comparison with heavier and larger engines. It also adds to the usefulness of the engine at various areas due to the compactness and cost effectiveness gained. This also helps to achieve the Euro-VI norms well within the limit.

Various parameters considered to achieve downsizing are as follows:-

(i) Using Integrated Exhaust Manifold

(ii) Using Split Cooling

(iii) Using a Dual Mass Flywheel

(iv) Belt drive through oil

Integrating the exhaust manifold to the engine manifold greatly reduces space and cost of the engine. So turbo charging techniques can be applied more efficiently as well as it provides a good aes thetic look to the engine.

During the working of any engine, the heat generated in the process, gets localized at certain points of the engine. Also we find different heat demands at different regions. Hence it is necessary to optimize and regulate the flow of heat throughout the engine to get maximum performance. Hence, Split cooling technique is in demand. It efficiently cools down the critical areas, thus reduces the necessity to cool each and every part of the engine. It generally comprises of a water jacket and a distributor. Owing to its higher heat 
carrying capacity and easy availability, water is chosen as the coolant. The advantages of this method are that it allows maintaining optimum temperatures at different points and increases overall effect of the cooling system on performance of the engine.

We can also use a dual mass flywheel to ensure an uninterrupted supply of energy and reduced vibrations. Since vibrations are reduced, thus it saves much of the useful energy that would have otherwise been lost due to these vibrations.



Fig 10:- Is ometric view of piston

The transmission system also adds to the weight and size of the engine. Chain drives generally used in conventional engines are heavy, and costly as compared to belt drives. On the other hand, a belt drive dipped in oil can serve as a promising alternative to the chain drive. The various advantages that tempt us to adopt this drive are noiseless and vibration-free operation, low cost, lightweight and resistant to corrosion.

\section{CONCLUSION}

It is expected that the improvements suggested during the design of the GDI engine will enhance the fuel economy as well as engine output. The inclusion of the piezoelectric injector also helped in reduction of the overall weight of the engine. The proposal was done keeping in mind the existing emission norms such as Euro-VI. Gasoline direct injection combined with turbo charging, EGR and implementation of scavenging techniques is expected to give promising results when implemented in automobiles

\section{REFERENCES}

[1].http://products.bosch-mobility-

solutions.com/en/de/powertrain/powertrain_systems_for_pa ssenger_cars_1/direct_gasoline_injection/direct_gasoline_in jection_23.html

[2].www.bosch.co.jp/tms 2015/en/products/pdf/DS-Sheet-

Scavenging_EN_low.pdf
[3]. Baumgarten C., Mixture Formation in Internal Combustion Engines, Springer Verlag, Germany, 2006.

[4]. Zhao F., Lai M. C., Harrington D. L., "Automotive Spark-Ignited Direct-Injection Gasoline Engines, Progress in Energy and Combustion Science", Volume 25, Issue 5, October 1999, Pages 437-562.

[5]. Majkowski. Stephen, "Filtration of gasoline direct injection engine exhausts with honeycomb filters", US Patent WO2014085325 A1, June 5, 2014

[6]. Sharma R.P, Mathur M.L, "Internal Combustion Engines", 2010, DhanpatRai Publications.

[7]. Website3:http://www.caranddriver.com/features/techdepartment-piezo-fuel-injectors-explained

[8].Website4:https://www.intechopen.com/books/fuelinjecti on/gasoline-direct-injection

[9].Website5:https://en.wikipedia.org/wiki/European_emis si on_standards

[10].Website6:https://energy.gov/sites/prod/files/2014/04/f1 4/fy13advancedcombustionprogress report.pdf

\section{BIOGRAPHIES}

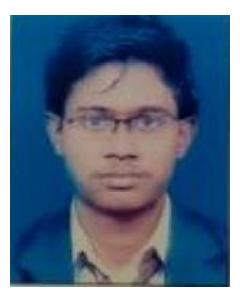

Jai Shankar is currently pursuing his Bachelor in Technology degree in Mechanical Engineering at College of Engineering and Technology, Bhubaneswar, Odisha, India. He was the Captain of the HPVC (Human Powered Vehicle Challenge) Team the "Gutsy Gladiators" that secured $6^{\text {th }}$ rank in Design Event at ASME HPVC INDIA 2017 held at LNMIIT, Jaipur. Had also represented the college at ASME HPVC INDIA 2016 held at VIT, Vellore and secured $7^{\text {th }}$ rank in Innovation event. He has done his internships from NALCO (National Aluminium Company), RSP(Rourkela Steel Plant) and at AUTONEXT, Jamshedpur. His soft skills include CATIA, ANSYS and MATLAB. He can be contacted through his email address: asme.jaishankar@gmail.com

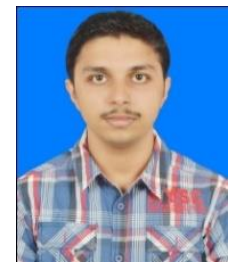

Ashutosh Sahu is currently pursuing his Bachelor in Technology degree in Mechanical Engineering at College of Engineering and Technology, Bhubaneswar, Odisha, India. He was the Vice-Captain of the HPVC (Human Powered Vehicle Challenge) Team the "Gutsy Gladiators" that won $6^{\text {th }}$ rank in Design Event at ASME HPVC INDIA 2017 held at LNMIIT, Jaipur. Had also represented the college at ASME HPVC INDIA 2016 held at VIT, Vellore and secured $7^{\text {th }}$ rank in Innovation event. He has done his internships from Vizag Steel Plant, Visakhapatnam and at AUTONEXT, Jamshedpur. His soft skills include CATIA, ANSYS and MATLAB. He can be contacted through his email address: sahoo.ashutosh0@gmail.com 